\title{
THE INFLUENCE OF THE REGIONAL BASIC DIET FROM NORTHEAST BRAZIL ON HEALTH AND NUTRITIONAL CONDITIONS OF MICE INFECTED WITH SCHISTOSOMA MANSONI.
}

\author{
Eridan M. Coutinho, Lucila P.C.G. de Freitas and Frederico G.C. Abath
}

\begin{abstract}
Protein nutritional status indicators were studied in weanling albino Swiss mice infected with S. mansoni and fed the Regional Basic Diet (RBD) from Northeast Brazil, a multideficient diet of low-protein content. Each mouse was infected percutaneously with 80 cercariae. The experiment lasted 63 days. The growth curve, food consumption, protein intake, weight gain, Protein Efficiency Ratio (PER) and Net Protein Ratio (NPR) were the parameters investigated. $R B D-f e d$ mice showed a marked weight loss, a lower food and protein intake, a slower body weight gain and lower rates of food protein utilization when compared to casein-fed animals. Differences between infected and non-infected mice were not consistent. The present results suggest that the effects of RBD-induced malnutrition on health and nutritional conditions of the mice are more severe than those of Manson's schistosomiasis, in the initial phase of the disease.
\end{abstract}

Key-words: Schistosoma mansoni. Mice. Malnutrition. Protein.

Malnutrition areas and major Schistosoma mansoni endemic foci overlap considerably in Northeast Brazil ${ }^{9}$. Multiple deficiencies, mainly of the calorie-protein type, have been detected in the population living in these areas 5910121423 . Based on food habits of this population, a definition was possible for the Regional Basic Diet (RBD), a food blend of low protein content (kidney beansPhaseolus vulgaris, manioc flour-Manihot esculenta, salted and dried meat-"charque"and sweet potatoes-Iponaea batatas), which reproduces dietary deficiencies prevalent in the region ${ }^{9} 1132$. To manioc flour and sweet potatoes have been ascribed the amino acid imbalance and further decrease in the protein content of this multideficient diet.

A type of malnutrition rather similar to the marasmatic form of calorie-protein malnutrition seen in humans, which is quite common in Northeast Brazil, has been induced in weanling mice ${ }^{911}$ and

\footnotetext{
Centro de Pesquisas Aggeu Magalhães (Fundação Oswaldo Cruz) Recife, PE, Brazil.

Supported by CNPq and FACEPE.

Address for correspondence: Dra. Eridan M. Coutinho. Centro de Pesquisas Aggeu Magalhães/FIOCRUZ, CP: 7472, 50722-970 Recife, PE, Brazil.

Recebido para publicaçāo em 19/08/91.
}

rats $^{2132}$ fed RBD. In addition to growth disturbances ${ }^{9}$ 112132, RBD intake results in a deficient glycemic regulation $^{33}$, a reduction in the sciatic nerve conduction velocity ${ }^{28}$ and impaired propagation of spreading depression in the cerebral cortex of SpragueDawley rats ${ }^{19}$.

For further information on the effects of RBD on the initial phase of experimental mansonic schistosomiasis in albino mice, particularly on the protein nutritional status of the host, biological assays (Protein Efficiency ratio-PER and Net protein Ratio-NPR) were performed to determine the utilization of dietary protein. In addition, some other indicators of protein metabolism ${ }^{25}$, such as the weight gain, growth curve, food consumption and protein intake were investigated.

The proposed experimental model reproduces the relationship between undernourished host and parasite infection as it is found among Brazilian populations living in schistosomiasis endemic areas. The experiment was designed: 1) to study the effects on the host, of malnutrition induced by RBD intake; 2) to detect, by using some indicators of protein nutritional status, the influence of this diet on protein utilization in the body of mice infected with $S$. mansoni as compared to non-infected controls. 
Coutinho EM, Freitas LPCG, Abath FGC. The influence of the regional basic diet from northeast Brazil on health and nutritional conditions ofmice infected with Schistosoma mansoni. Revista da Sociedade Brasileira de Medicina Tropical 25:13-20, jan-mar, 1992.

\section{MATERIALS AND METHODS}

\section{Diets}

The Regional Basic Diet (RBD) is based on human staple foods usually ingested in Northeast Brazil (kidney beans-Phaseolus vilgaris, manioc flour-Manihot esculenta, salted and dried meat and sweet potato-Iponaea batatas). It has the following composition ( $\mathrm{g} / 100 \mathrm{~g})$ : kidney beans (proteins3.96 , carbohydrates-10.66, fats- 0.24 , minerals0.57 , fibers-1.09); manioc flour (proteins-0.82, carbohydrates-48.59, fats- 0.12 , minerals- 0.43 ), fibers-5.64); "charque" (proteins-2.74, carbohydrates -0.43 , fats -0.21 , minerals -0.06 ); fat from "charque"(fat- 0.35 ); sweet potato (proteins0.30 , carbohydrates -9.99 , fats -0.03 , minerals -0.20 , fibers-0.48). This food blend contains, per $100 \mathrm{~g}$, $7.82 \%$ proteins, $69.67 \%$ carbohydrates, $0.95 \%$ fats and $1.26 \%$ fibers. Both control diets contained casein and had different total protein levels: $7.82 \%$ (control diet $I$ ) and $22.60 \%$ (control diet II).

The control diet $I$ had the following composition ( $\mathrm{g} \%$ ): casein (protein-7.06), soybean oil (fat 8.00), corn starch (protein-7.76, carbohydrate-74.37), cellulose (fibers-3.50).

The control diet II had the following composition (g\%): casein (protein-22.09), soybean oil (fat13.00), corn starch (protein-0.51, carbohydrate50.19), cellulose (fibers-4.00).

Both control diets were supplemented with mineral salts $(2.50 \mathrm{~g} \%)$ and vitamin mixtures $(1 \mathrm{~g} \%$ water-soluble and $1 \mathrm{~g} \%$ fat-soluble vitamins), according to Tagle \& Donoso ${ }^{31}$. All these diets were given in pellet form.

The non-protein diet, used in the Net Protein Ratio biological assay (NPR), was composed as follows ( $\mathrm{g} \%$ ): soybean oil (fat-8.00), mineral salts (4.00), fat-soluble vitamin mixture (1.00), watersoluble vitamin mixture $(1.00)$, corn starch (protein0.82 , carbohydrates- 72.03 , fat- 0.16 , mineral salts0.12 ), cellulose (fibers-4.00). It was given during 10 days to a group of 10 animals used as controls for that assay.

\section{Experimental animals}

A total of 70 albino Swiss mice were used. Twenty male and female animals were fed each diet and divided into infected and non-infected subgroups of 10 mice each. An additional group of 10 noninfected mice was given a non-protein diet and was used as control for the Net Protein Ratio biological assay.

\section{Infection}

A S. mansoni strain isolated from São Lourenço da Mata (Pernambuco State, Brazil) and maintained regularly in our laboratory was used. Each animal was infected percutaneously with 80 cercariae shed from Biomphalaria glabrata reared and infected in the laboratory (infections up to 100 to 150 cercariae per mouse are well tolerated ${ }^{2434}$ ).

\section{Experimental protocol}

Twenty-one-day old weanling mice weighing 9 to $12 \mathrm{~g}$ were kept in individual wire bottom cages. Water and diets were provided "ad libitum". The body weight was determined weekly and the food intake was recorded daily. The experiment lasted 63 days.

Subgroups of 5 mice per control diet were submitted to a pair-feeding trial along the first 28 days of the experiment. So, the daily food intake of control mice (diets I and II) was restricted to the "ad libitum" intake of RBD-fed animals.

The post-weanling rapid growth period of the mouse was observed during the first 28 days of the investigation (Phase I). Henceforth, the $S$. mansoni oviposition and maturation of hepatic and intestinal lesions were investigated (Phase II).

\section{Indicators of the protein nutritional status}

The weight curve, total food consumption, protein intake, weight gain, Protein Efficiency Ratio (PER) and Net Protein Ratio (NPR) values were the parameters studied. PER is a biological assay devised to determine the grams gain per gram protein consumed, while NPR measures the weight loss of a negative control group fed a non-protein diet, added to the weight gain of the experimental group (RBD-fed mice) and divided by the protein consumed by the latter ${ }^{22}$.

\section{Statistical analysis}

The analysis of variance and Student's " $t$ " test 
Coutinho EM, Freitas LPCG, Abath FGC. The influence of the regional basic diet from northeast Brazil on health and nutritional conditions ofmice infected with Schistosoma mansoni. Revistada Sociedade Brasileira de Medicina Tropical 25:13-20, jan-mar, 1992.

Table 1 - Mean food intake(g) of infected and non-infected mice fed RBD and Casein diets.

\begin{tabular}{|c|c|c|c|}
\hline $\begin{array}{l}\text { Diets and Animal } \\
\text { subgroups }\end{array}$ & $\begin{array}{c}\text { Phase I } \\
(\overline{\mathrm{X}} \pm \text { SEM })\end{array}$ & $\begin{array}{c}\text { Phase II } \\
(\bar{X} \pm \text { SEM })\end{array}$ & $\begin{array}{l}\text { Overall experimental } \\
\text { period } \\
(\overline{\mathrm{X}} \pm \mathrm{SEM})\end{array}$ \\
\hline $\begin{array}{l}\text { RBD (infected) } \\
\text { RBD (non-infected) }\end{array}$ & $\begin{array}{r}89.15 \pm 9.31 \\
114.60 \pm 4.29 \\
\text { Significant }(\mathrm{p}<0.05)\end{array}$ & $\begin{array}{r}88.94 \pm 7.97 \\
141.00 \pm 8.16 \\
\text { Significant }(p<0.0001)\end{array}$ & $\begin{array}{r}191.99 \pm 21.54 \\
257.01 \pm 10.68 \\
\text { Significant }(\mathrm{p}<0.02)\end{array}$ \\
\hline $\begin{array}{l}7.82 \% \text { casein (infected) } \\
7.82 \% \text { casein (non-infected) }\end{array}$ & $\begin{array}{r}107.05 \pm 6.87 \\
94.72 \pm 7.26 \\
\text { Non-significant }\end{array}$ & $\begin{array}{r}135.35 \pm 11.53 \\
172.91 \pm 11.62 \\
\text { Significant }(p<0.05)\end{array}$ & $\begin{array}{r}242.40 \pm 11.95 \\
270.23 \pm 14.57 \\
\text { Non- significant }\end{array}$ \\
\hline $\begin{array}{l}22.60 \% \text { casein (infected) } \\
22.60 \% \text { casein (non-infected) }\end{array}$ & $\begin{array}{r}121.68 \pm 7.73 \\
108.46 \pm 7.36 \\
\text { Non-significant }\end{array}$ & $\begin{array}{r}125.55 \pm 7.29 \\
138.20 \pm 3.75 \\
\text { Non-significant }\end{array}$ & $\begin{array}{r}243.83 \pm 13.61 \\
240.84 \pm 12.77 \\
\text { Non-significant }\end{array}$ \\
\hline
\end{tabular}

$\overline{\mathrm{X}}=$ arithmetic mean

$\mathrm{SEM}=$ standard error of the mean

Phase I $=$ The first 28 days after weanling.

$\mathrm{RBD}=$ Regional Basic Diet

Phase II $=$ From the 29 th day to the end of the trial Table 2 - Proteins efficiency ratio of infected and non-infected micefed the Regional Basic Diet and Casein
diets (controls)*.

\begin{tabular}{llc}
$\begin{array}{l}\text { Diets and Animal } \\
\text { subgroups }\end{array}$ & $\begin{array}{l}\text { PER } \\
(\mathrm{X} \pm \mathrm{SEM})\end{array}$ & Student's " $t$ " test \\
\hline
\end{tabular}

RBD (infected)

$0.59 \pm 0.08$

$\mathrm{x}$

$1.64 \pm 0.08$

Significant $(p<0.001)$

$7.82 \%$ casein (infected)

$0.59 \pm 0.08$

RBD (infected)

$1.93 \pm 0.08$

Significant $(p<0.001)$

$7.82 \%$ casein (non-infected)

RBD (non-infected)

$1.04 \pm 0.08$

$x$

$1.93 \pm 0.23$

Significant $(p<0.005)$

$7.82 \%$ casein (non-infected)

$\overline{\mathrm{X}}=$ arithmetic mean

SEM = standard error of the mean

$\mathrm{RBD}=$ Regional Basic Diet

PER = protein efficiency ratio biological assay

(*) This assay was not performed for the subgroup fed $22.60 \%$ casein diet because a protein content lower than $10 \%$ is required.

showed that the infected RBD-fed mice had the lowest values for the body weight gain. Pair-fed animals also showed significantly $(\mathrm{p}<0.01)$ lower body weight gains in RBD-fed mice.

\section{Indicators of food protein utilization}

PER was determined for the two low-protein diets (RBD and control diet I), both with a protein 
Coutinho EM, Freitas LPCG, Abath FGC. The influence of the regional basic diet from northeast Brazil on health and nutritional conditions ofmice infected with Schistosoma mansoni. Revista da Sociedade Brasileira de Medicina Tropical 25:13-20, jan-mar, 1992.

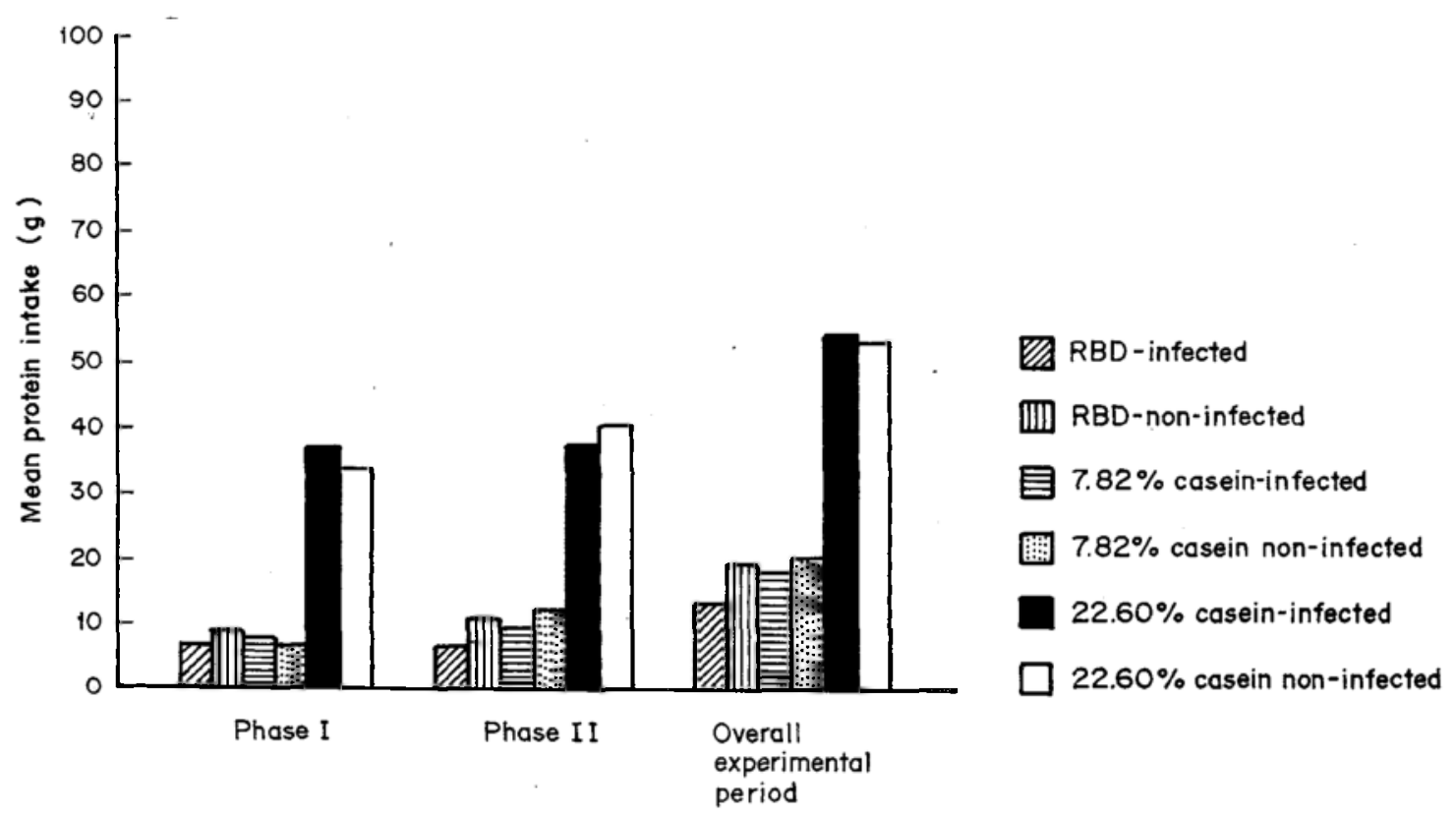

Figure 2 - Mean protein intake of infected and non-infected mice fed RBD and Casein diets.

Table 3 - Net Protein Ratio of infected and non-infected mice fed the Regional Basic Diet and Casein diets*.

\begin{tabular}{lcc}
\hline $\begin{array}{l}\text { Diets and Animal } \\
\text { subgroups }\end{array}$ & $\begin{array}{l}\text { NPR } \\
(X \pm S E M)\end{array}$ & Student's "t" test \\
\hline
\end{tabular}

RBD (infected)

$1.68 \pm 0.23$

RBD (non-infected)

$2.08 \pm 0.17$

Non-significant $(p>0.05)$

$7.82 \%$ casein (infected)

$3.99 \pm 0.52$

$7.82 \%$ casein (non-infected)

$4.90 \pm 0.50$

Non-significant $(p>0.05)$

$\mathrm{X}=$ arithmetic mean

SEM $=$ standard error of the mean

RBD $=$ Regional Basic Diet

$\mathrm{NPR}=$ net protein ratio biological assay

(*) This assay was not performed for the subgroup fed $22.60 \%$ casein diet because a protein content lower than $10 \%$ is required.

level below $10 \%$ as required for this biological assay. Only RBD groups showed a significant difference regarding PER values $(p<0.002)$ between infected and non-infected mice. When the groups were compared to each other, again the lowest values were detected in the RBD-fed mice, particularly when $S$. mansoni infection was associated (Table 2). NPR values were apparently higher for the non-infected mice. However, results were not statistically significant (Table 3 ).

\section{DISCUSSION}

Although over the past 35 years significant relationships between schistosomiasis and nutritional 
Coutinho EM, Freitas LPCG, Abath FGC. The influence of the regional basic diet from northeast Brazil on health and nutritional conditions ofmice infected with Schistosoma mansoni. Revista da Sociedade Brasileira de Medicina Tropical 25:13-20, jan-mar, 1992.

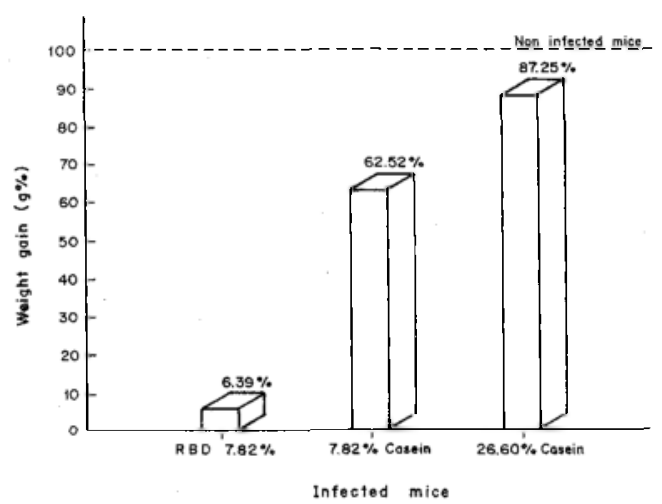

Figure 3 - Weight gain of infected and non-infected mice fed RBD and Casein diets.

status have been reported, the public health importance of these findings in schistosomiasisinfected communities is still unclear ${ }^{30}$. On the other hand, these investigations are important in estimating to what extent a community may benefit from the control of schistosomiasis per se even if the nutritional situation remains unchanged ${ }^{6}$.

The lack of proteins is the principal nutritional problem in our days, being a constant finding among the populations of developing areas.

The nutritive value of several diets used by human populations has been assessed in experimental animals ${ }^{182629}$. Although human and murine growth rates and nutritional needs can not be assumed to be at all closely related, the present experimental model seemed to us more adequate. Results obtained from experimental studies using purified or semisynthetic diets fed to laboratory animals can hardly be extrapolated to man, because they do not reproduce the natural conditions to which human populations are exposed. Our diet (RBD), based on northeastern staple foodstuffs, is a multideficient diet with a lowprotein content and is responsible for different nutritional deficiencies occurring in this region of the country. The essential and non-essential amino acid contents of RBD ranges from 16 to $44 \%$ (methionine and arginine, respectively) and from 10 to $81 \%$ (proline and cystine, respectively).

Clear cut alterations of protein metabolism have been described in man 671317 and experimental animals ${ }^{315}$ infected with $S$. mansoni, particularly in the hepato/splenic stage of the disease.
A decreased protein and lipid utilization was reported in infected mice and was ascribed to the altered hepatic function or to the acute intestinal inflammation seen in this experimental host ${ }^{16}$.

PER and NPR assays have been extensively used in evaluating the nutritive value of food proteins $^{22}$. In the present investigation, these indicators were consistently lower in RBD-fed mice; infected animals presented the lowest values.

Clinical, epidemiological and experimental studies have suggested that deficiency states induced by malnutrition depress host defense mechanisms, aggravating the course of infectious and parasitic diseases, including schistosomiasis ${ }^{27}$. However, this has not been supported by some investigations in humans ${ }^{9}{ }^{30}$. Some experiments suggest that the appearance of the clinical symptoms of schistosomiasis depends on the host's nutritional status $^{1} 23420$. According to previous findings, however, schistosome infection only contributes to aggravate malnutrition ${ }^{9} 1011$.

In conclusion, the data presented in this paper indicate that, at least in the initial stage of the disease and under our experimental conditions, the harmful effects of RBD-induced malnutrition are more severe than those of Manson's schistosomiasis.

\section{RESUMO}

Indicadores do estado nutrictional de proteínas foram estudados em camundongos albinos suiços recémdesmamados e infectados com S. mansoni, aos quais foi administrada a Dieta Básica Regional (DBR) do Nordeste do Brasil. Cada camundongo foi infectado com 80 cercárias, por via percutânea. $O$ experimento teve a duração de 63 dias. Os parâmetros investigados foram: evolução ponderal, consumo alimentar, ingestão protéica, ganhoponderal, Coeficiente de Eficiência Protéica (PER) e Coeficiente de Eficiência Protéica Líquida (NPR). Os camundongos alimentados com a DBR revelaram acentuada perda de peso, menor consumo alimentar $e$ protéico, maior lentidão no ganho em peso relacionado com a fase de crescimento e taxas menos elevadas de utilização da proténa dietética, quando comparados com os controles (alimentados com dieta balanceada, $a$ base de 22,60\% de caseina). As diferenças encontradas entre camundongos infectados e não infectados, não foram consistentes. Os resultados sugerem que os efeitos provocados pela má-nutrição induzida pelo consumo da $D B R$ são muito mais perniciosos para a saúde e estado 
Coutinho EM, Freitas LPCG, Abath FGC. The influence of the regional basic diet from northeast Brazil on health and nutritional conditions ofmice infected with Schistosoma mansoni. Revista da Sociedade Brasileira de Medicina Tropical 25:13-20, jan-mar, 1992.

nutricional do hospedeiro, do que aqueles resultantes da infecção pelo S. mansoni, na fase inicial da doença.

Palavras-chaves: Schistosoma mansoni. Camundongos. Má-nutrição. Proteínas.

\section{ACKNOWLEDGEMENTS}

We are indebted to Miss Lígia Pedrosa for her critical review and Miss Ivanilda V. Nascimento for typing the manuscript.

\section{REFERENCES}

1. Akpom CA. Supression of granulome formation around Schistosoma mansoni eggs in severe protein malnutrition: the role of the egg. Transactions of the Royal Society of Tropical Medicine and Hygiene 75:444-446, 1981.

2. Akpom CA. Schistosomiasis: nutritional implications. Reviews of Infectious Diseases 4:776782, 1982.

3. Akpom CA, Warren KS. Calorie and protein malnutrition in chronic murine schistosomiasis mansoni: effect on the parasite and the host. The Journal of Infectious Diseases 132:6-14, 1975.

4. Akpom CA, Warren KS. The inhibition of granulome formation around Schistosoma mansoni eggs. VI. Protein, calorie and vitamin deficiency. American Journal of Pathology 79:435-452, 1975.

5. Batista Filho M, Chaves N, Varela RM, Martin MHS, Salzano AC, Bazante MO, Teixeira SMG, Lima EJC, Reis FM, Martins GC, Linhares ER. Inquérito nutricional em área urbana da Zona da Mata do Nordeste brasileiro (Água Preta, Pernambuco). O Hospital 79:707-723, 1971.

6. Chen MG, Mott KE. Progress in assessment of morbidity due to Schistosoma mansoni infection (A review of recent literature). Tropical Diseases Bulletin 85:1-56, 1988.

7. Coutinho A, Loureiro P. Aspectos bioquímicos da insuficiência hepática na esquistossomose mansônica hepato-esplenica. Anais da Faculdade de Medicina da Universidade de Recife 20:27-49, 1960.

8. Coutinho EM. Observações preliminares sobre o padrão dietético em áreas endêmicas de esquistossomose mansônica. Jornal Brasileiro de Medicina 8:339-344, 1964.

9. Coutinho EM. Relações hospedeiro-parasito na esquistossomose mansônica, em função da Dieta Básica Regional (Estudo epidemiológico c anatomopatológico). Tese de Doutorado, Universidade Federal de Pernambuco, Recife, PE, 1976.

10. Coutinho EM. Estado nutricionale esquistossomose. Revista da Sociedade Brasileira de Medicina Tropical 13:91-96, 1980.

11. Coutinho EM. Patobiologia da desnutrição nas doenças parasitárias. Memórias do Instituto Oswaldo Cruz 75:63-76, 1980.

12. Coutinho EM, Amaral JA, Barbosa JM. Alterações bioquímicas na esquistossomose mansônica humana, com especial referência ao metabolismo lipídico. Jornal Brasileiro de Medicina 11:157-168, 1966.

13. Coutinho EM, Barbosa FS, Barbosa JM, Pessoa D, Pinto RF, Oliveira PA, Rodrigues BA. Inquérito clínico-nutricional e antropométrico preliminar, em áreas endêmicas de esquistossomose mansônica, no Nordeste do Brasil. Revista da Sociedade Brasileira de Medicina Tropical 6:211-236, 1972.

14. Coutinho EM, Costa LP, Salzano AC, Campos FS, Melo MEB, Lapa A. Níveis e tipos de proteína alimentar e suas repercussões sobre a biologia do hospedeiro, na esquistossomose experimental ( $S$. mansoni) do camundongo albino. In: Anais da

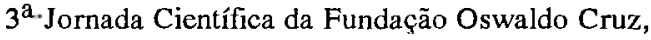
Rio de Janeiro p. 454-455, 1985.

15. Coutinho EM, Espírito Santo M, Barbosa JM, Mello SA. Padrão alimentar em áreas endêmicas de esquistossomose mansônica, no Nordeste do Brasil. Revista Brasileira de Malariologia e Doenças Tropicais 16:553-589, 1964.

16. De Witt WB. Effects of Schistosoma mansoni infections on the ability of mice to digest and absorb dietary fats and proteins. The Journal of Parasitology 43:32, 1957.

17. De Witt WB, Oliver-González J, Medina E. Effects of improving the nutrition of malnourished people infected with Schistosoma mansoni. The American Journal of Tropical Medicine and Hygiene 13:2535, 1964.

18. Gale MM, Crawford MA. The effect of African staple foodstuffs on guinea-pig growth curves. Transactions of the Royal Society of Tropical Medicine and Hygiene 63:821-825, 1969.

19. Guedes RCA, Andrade AFD, Cabral Filho JE. Propagation of cortical spreading depression in malnourished rats: facilitatory effect of dietary protein deficiency. Brazilian Journal of Medical and Biological Research 20:639-642, 1987.

20. Knauft RF, Warren KS. The effect of calorie and protein malnutrition on both the parasite and the host 
Coutinho EM, Freitas LPCG, Abath FGC. The influence of the regional basic diet from northeast Brazil on health and nutritional conditions of mice infected with Schistosoma mansoni. Revista da Sociedade Brasileira de Medicina Tropical 25:13-20, jan-mar, 1992.

in acute murine schistosomiasis mansoni. The Journal of Infectious Diseases 120:560-575, 1969.

21. Lago ES, Pessoa DCNP, Teodósio NR, Cabral Filho JE. Longevity and growth curve of chronically malnourished rats fed the Regional Basic Diet (RBD). In: Abstract of the $2^{\text {nd }}$ International Symposium of Nutrition, Proceedings, Recife p.40-41, 1988.

22. McLaughlan JM, Campbell JA. Methodology of protein evaluation. In: Munro HN (ed) Mammalian protein metabolism, Academic Press, New York, vol. 3 p.391-422, 1969.

23. Mello AV, Baez MC, Bazante MD, Coelho HAL, Martins MHS, Paes AG, Dantas LYS. Inquérito de consumo alimentar no município de Catende, Zona da Mata Sul de Pernambuco. Boletim do Instituto de Nutrição da Universidade Federal de Pernambuco 1:7-49, 1973.

24. Moore DV, Yolles TK, Meleney HE. A comparison of common laboratory animals as experimental hosts for Schistosoma mansoni. The Journal of Parasitology 35:156-170, 1949.

25. Oliveira JED, Santos AC, Wilson ED. Nutrição Básica, Editora Sarvier, São Paulo, 1982.

26. Ramos-Aliaga R. Aspectos bioquimicos y nutricionales en ratas en desarrollo que reciben proteinas de dos patrones dietarios de los Andes del Peru. Archivos Latinoamericanos de Nutrición 28:378-400, 1978.

27. Scrimshaw NS, Taylor CE, Gordon JE. Nutrición y Infecciones: su acción reciproca. Organización Mundial de la Salud (OMS: Serie monografias $n^{\circ}$ 57) Genebra, 1970.

28. Silva AT, Costa FBR, Costa JA, Teodósio NR,
Cabral Filho JE, Guedes RCA. Sciatic nerve conduction velocity of malnourished rats fed the human "Basic Regional Diet" of the northeast of Brazil. Brazilian Journal of Medical and Biological Research 20:383-392, 1987.

29. Souza N, Elias LG, Bressani R. Estudios, en ratas, del efecto de una dieta básica del medio rural de Guatemala, suplementada con leche de vaca y una mezcla de proteinas. Archivos Latinoamericanos de Nutrición 20:293-307, 1970.

30. Stephenson LS. Schistosomiasis and human nutrition. Cornell International Nutrition Monograph Series no. 16, New York p.1-21, 1986.

31. Tagle MA, Donoso G. Net protein utilization determined in short and long term experiments with rats. Journal of Nutrition 87:173-178, 1965.

32. Teodósio NR, Lago ES, Medeiros MC, Ferreira LMP, Santos ETV. Carbohydrate metabolism in malnutrition induced by the Regional Basic Diet. 1. Fasting glycemia and liver glycogen in rats with RBD-induced malnutrition. In: Abstract of the $1^{\text {st }}$ International Symposium of Nutrition, Proceedings, Recife p.40-41, 1986.

33. Teodósio NR, Romani SAM, Lago ES. Dietary deficiencies and malnutrition. 1. An experimental dietetic model. In: Abstract of the $1^{\text {st }}$ International Symposium of Nutrition Proceedings, Recife p.3839, 1986.

34. Warren KS. The influence of treatment on the development and course of murine hepato-splenic schistosomiasis mansoni. Transactions of the Royal Society of Tropical Medicine and Hygiene 56:510$519,1962$. 